\title{
Die Dordtse Leerreëls: Inklusief of eksklusief?
}

Author:

Barry van Wyk ${ }^{1}$

\section{Affiliation:}

${ }^{1}$ Unit for Reformed Theology, North-West University,

South Africa

Corresponding author:

Barry van Wyk,

bvw@vodamail.co.za

Dates:

Received: 08 Dec. 2017

Accepted: 24 May 2018

Published: 11 Sept. 2018

How to cite this article: Van Wyk, B., 2018, 'Die Dordtse Leerreëls: Inklusief of eksklusief?', In die Skriflig 52(2), a2337. https://doi. org/10.4102/ids.v52i2.2337

\section{Copyright:}

C 2018. The Authors. Licensee: AOSIS. This work is licensed under the Creative Commons Attribution License.
The Canons of Dordt: Inclusive or exclusive? This article starts with a historic background of the relevant circumstances which should be acknowledged to understand the reasons why a Synod of this stature was held at Dordrecht in 1618-1619. In view of the main agenda resulted from the Remonstrance formulated by the Remonstrants in 1610, most parts of the Synod were attended to discuss the Remonstrance which ended with the Remonstrants being suspended from the Synod. The question is also answered whether the Canons of Dordt are exclusive or inclusive.

\section{Inleidend}

In die onderhawige artikel word aangedui dat die mening dat in die Dordtse Leerreëls (DL) met 'n meedoënlose predestinasie gewerk word (vgl. Nederduitsch Hervormde Kerk van Afrika [NHKA] 2016a:779-794; 2016b:194-196), nie reg aan die inhoud en bedoeling van die Dordtse Leerreëls laat geskied nie. Hierdie siening kom daarop neer dat sommige mense buite Christus om van ewigheid af uitverkies of verwerp is. Die Leerreëls kan as ' $n$ formulier van eenheid, tot troos van gelowiges gehandhaaf word. Daar word toegegee dat die omgang met die betrokke belydenisskrif hermeneuties bepaald moet wees om reg aan die inhoud te laat geskied en ontnugtering te voorkom. Die Dordtse Leerreëls is derhalwe nie eksklusief nie, maar inklusief.

Die Dordtse Leerreëls (1618-1619) vorm deel van die sogenaamde formuliere van eenheid (vgl. Bakhuizen van den Brink 1976:49-50), naas die Nederlandse Geloofsbelydenis ([NGB] 1561) en die Heidelbergse Kategismus ([HK] 1563). Die Sinode wat in Dordrecht plaasgevind het, was in die sinodes sedert Emden (1571) 'n bepaalde afsluiting van die kerkregtelike ontwikkeling en formulering van die kerkorde wat tydens hierdie Sinode vasgestel is. Naas die kerkordelike stryd was daar ook 'n stryd om die belydenis van die kerk, wat hand aan hand met seggenskap van die owerheid in die kerk geggaan het. Die klem op menslike vryheid en verantwoordelikheid loop uit op 'n nasionaal gereformeerde beweging wat ten gunste was van die owerheid se inspraak in die kerk en wat die binding aan die belydenis krities bejeën het.

Die sogenaamde 'kerkelijken' het egter die invloed van die owerheid in die kerk afgewys en was ten gunste van die handhawing van die belydenis soos in die Nederlandse Geloofsbelydenis en die Heidelbergse Kategismus verwoord is. Slegs 'een confessionele basis kon aan de Gereformeerde Kerk een identiteit verlenen, die hem theologisch en sociaal opzicht van andere confessies onderscheidde'. Dit was veral die standpunt van Gomarus en die latere ContraRemonstrante $^{1}$ (Selderhuis 2006:414-415). Die bedoeling was egter nie om 'n addisionele belydenis tot die kerk se belydenisskat toe te voeg nie, maar om die dispuut tussen hierdie twee strydende partye tot 'n einde te bring (Sinnema 2011b:313).

Die verrigtinge van die Sinode is oorskadu deur die dispuut wat tussen twee hoogleraars aan die Universiteit van Leiden ontstaan het, naamlik Jacobus Arminius (1560-1609) en Franciskus Gomarus (1563-1641), asook hulle volgelinge (Pont 1994:85; vgl. Van 't Spijker 1987a:32).

\section{Agtergrond en aanloop tot die Sinode van Dordrecht 1618-1619}

Arminius, gebore in 1560 op Oudewater (Hoeksema 1980:6), word vanaf sy aanstelling as hoogleraar aan die Universiteit van Leiden (1603) bekend, ondanks die feit dat 'n Amsterdamse predikant, Petrus Plancius (1552-1622) hom reeds van onregsinnigheid beskuldig het (Pont 1994:85). Arminius se siening oor die predestinasie tree aan die lig in 'n disputatie (redestryd) voor studente op 7 Februarie 1604 (Selderhuis 2006:417) waarin hy 15 stellings behandel het. Johannes Wtenbogaert

1 Die Contra-Remonstrante was die party wat tydens die Dordtse Sinode hulle teen die remonstrantie (betoog of redeskrif) van die Remonstrante (die ander party) verweer het. 
(1557-1644), predikant in Utrecht en Den Haag en 'n student van Calvyn se opvolger Theodorus Beza (1519-1605), was van mening dat dít die grondoorsaak gevorm het van die spanning wat sou volg. In hierdie disputasie stel Arminius die volgende standpunt (Van 't Spijker 1987a):

De praedestinatie is een besluit van het welbehagen van God in Christus, waardoor God bij zichzelf van eeuwigheid besloten heeft, die gelovigen, die Hij met het geloof voorgenomen heeft te begiftigen, te rechtvaardigen, aan te nemen tot kinderen en hun het eeuwige leven te schonken, tot lof van zijn heerlijke genade. ... De reprobatie of verwerping is een besluit van de toorn, of van de strenge wil van God, waardoor God van eeuwigheid voorgenomen heeft, ... (bl. 34)

Navorsing oor Arminius se denke en die redes waarom hy afwyk van die hoofstroom sestiende-eeuse reformatoriese denke soos dit het in die debat oor die predestinasie gereflekteer het, is moontlik aan die volgende te wyte (Den Boer 2011):

Therefore, Arminius's view of the character, place, and function of God's iustitia is the deepest source and the main motive for his deviation from the 'mainstream' of late sixteenth-century Reformed theology, as represented by Calvin and Beza. His reflection on the relationship between God's justice and human sin led him to focus on God's justice as one of the most important and far-reaching assumptions of his whole theology. (bl. 47)

Die geskille gaan derhalwe nie net oor predestinasie nie, maar ook oor die status van die gereformeerde belydenis en die verhouding kerk-staat. Die situasie vererger toe Gomarus ook op 31 Oktober 1604 'n redestryd oor predestinasie hou waarin hy die supralapsariese standpunt van Beza verdedig het (Verboom 2005:22-23).

Vir Gomarus is God se beskikking ooreenkomstig sy wil bepalend. Arminius egter, maak die vrye keuse van die mens se wil bepalend in God se voorkennis, voorafgaande aan sy wil. Arminius vra dus hoe God se genade effektief kan wees sonder om die menslike vryheid aan te tas. Arminius maak 'n onderskeid tussen voldoende en effektiewe genade. Voldoende genade is die moontlikheid om te glo, maar eers indien iemand glo, word dit duidelik dat die genade wat hy ontvang het, effektief is. Voldoende genade kan afgewys word, maar effektiewe genade gaan altyd met aanvaarding gepaard. Sonder instemming van die ontvanger word voldoende genade nie effektief nie. 'Arminius stelde dat de vrije instemming van de mens steeds voorwaarde is voor het door God geschonken geloof' (Selderhuis 2006:418).

Gomarus het dit teen Arminius se regverdigingsleer. Toe beide saam met vier predikante op las van die Staten op 30 Mei 1608 voor die Hoge Raad van de Staten van Holland verskyn, wy Gomarus ses artikels aan die regverdigingsleer en slegs drie aan predestinasie, terwyl Arminius geen artikel aan die regverdigingsleer afstaan nie, maar wel vyf artikels aan God se besluite (Van Itterzon 1979:124; vgl. Van 't Spijker 1987a:36). Die Staten poog op 12 Augustus 1609 nogeens om die saak te bemiddel onder voorsitterskap van Johan van Oldenbarnevelt (1547-1619), raadspensionaris of landsadvokaat van die Staten, waartydens gesprek gevoer is 'over de rechtvaardiging, de predestinatie en over de revisie van de belijdenis. Maar alle discussies waren vruchteloos' (Van 't Spijker 1987a:36).

Die omvang van die spanning en die radikale meningsverskil tussen bepaalde woordvoerders het onder andere uit die lykrede geblyk wat tydens die begrafnis van Arminius (oorlede op 19 Oktober 1609) gehou is deur P. Bertius (15651629), 'regent van het Statencollege', waarop Gomarus verplig gevoel het om te reageer. Bertius haal Joris Jorisz. Stricht aan wat tydens 'n preek in Broek, Waterland, die mening lug dat die val van Adam móés gebeur en so deur God verordineer is. Hy predik dat God sy Seun gestuur het om die menslike geslag te verlos, 'maar dat Hij dit eigenlijk niet echt bedoelde'. God laat sy Woord verkondig vir almal om te hoor, maar 'doch slechts van enkelen, die Hij zou verlossen'; en die wat verlore gaan het God 'van eeuwigheid daartoe geschapen' (Van 't Spijker 1987a:36-37).

In 1607 het 'n kommissie in 's-Gravenhage byeengekom om vir 'n moontlike generale sinode voor te berei. Hulle moes op versoek van die State antwoorde vir 'n aantal aspekte vind wat in verband met ' $n$ sinode staan wat in die vooruitsig gestel is. Uit die verskillende aspekte wat ter tafel was, is dit duidelik dat binding aan die belydenis en die vraag na die hersiening daarvan tot meningsverskil gelei het. Van Oldenbarnevelt benut die meningsverskil om die State te oortuig om nie aan 'n kerklike oplossing toe te gee en 'n generale sinode te belê om die geskil op kerklike wyse by te lê nie (Van 't Spijker 1987a:37-38).

Na die dood van Arminius (Van Itterzon 1979:147) word die leiding van die Remonstrante deur Wtenbogaert oorgeneem. Hy was hofprediker van Prins Maurits (1567-1625), die Stadhouer van Holland. Ook hy het besware teen die uitverkiesingsleer gehad soos dit deur die generasie na Calvyn verstaan is en formuleer op 14 Januarie 1610 saam met 43 predikante 'n Remonstrantie (betoog of redeskrif) (vgl. Pont 1994:88-89). Daarin stel hy dat die Nederlandse Geloofsbelydenis en die Heidelbergse Kategismus aan hersiening onderwerp kan word en derhalwe nie as maatstaf moet geld wanneer die owerheid 'n sinode byeenroep om die spanning by te lê nie. Die Remonstrantie (vgl. Verboom 2005:111-121) het uit vyf artikels bestaan, geskoei op 'n manuskrip van Arminius van 1608 (Pont 1994:87-88) wat deur Wtenbogaert geformuleer is (Verboom 2005:110).

Die indiening van die Remonstrantie is voorafgegaan deur die sogenaamde pamflettestryd in 1609 en 1610 waarvan Reijnier Donteclock, (gebore ongeveer 1545 en ná 1612 gesterf; Verboom 2005:124), predikant van Delft, (hy het ook 'n reeks ander pamflette gepubliseer) waarskynlik die belangrikste geag word (Graafland 1987b:127). Die redevoerings wat in 1604 deur Arminius sowel as Gomarus oor die uitverkiesing gehou is, is in 1609 in Leiden deur die universiteitsdrukker Ian Paets Iacobszoon gedruk (Verboom 2005:103). Donteclock word ernstig deur die predikant van Leiden, Joh. Arn. Corvinus (1582 of 1583-1650) teëgespreek (vgl. Van Itterzon 
1979:159-160). Volgens hom gaan dit oor die manier hoe God die mens sien. 'Volgens de supralapsariërs als ongeschapen, volgens de infrapalsariërs als geschapen en in Adam gevallen, en volgens Arminius als geschapen, gevallen en gelovig of ongelovig' (Graafland 1987b:135; vgl. Verboom 2005:105). Van Itterzon (1979:160) wys daarop dat die infralapsariese standpunt deur Donteclock bygevoeg word - dit word deur Festus Hommius (1576-1642), predikant in Leiden en opsteller van die Contra-Remonstrantie, ten spyte van sy eie standpunt, gevolg.

Naas die Remonstrante se Remonstrantie het die ContraRemonstrante 'n Contra-Remonstrantie (teenbetoog; vgl. Verboom 2005:135-143) opgestel tydens 'n samekoms op 11 Maart 1611 onder voorsitterskap van Petrus Plancius, predikant van Amsterdam (vgl. Pont 1994:89-91).

Die Remonstrantie van die Remonstrante word deur Van Oldenbarnevelt by die vergadering van die Staten van Holland ingedien wat die dokument aan verskillende klassikale vergaderings voorlê en waarop redelike beroering gevolg het. Die Staten besluit op voorstel van Van Oldenbarneveldt om 'n conferentie te reël waarop die twee partye in gesprek sou tree. Dit het op 10 Maart 1611 (Verboom 2005:110, 134) plaasgevind onder voorsitterskap van meester M. Berck, pensionaris van Dordrecht. Dit het as die Schriftelijke Conferentie bekend gestaan. In sy openingsrede roep hy die aanwesiges op om 'alle passien, affecten en animositeyten' af te lê, 'kortelyck en sylogistice' te debatteer sodat die konferensie 'tot Godes eere, welstant van den Lande en gerustheid der kercken' sal verloop (Verboom 2005:133-134). Die verweer wat uit die geledere van die Contra-Remonstrante afkomstig was en as Contra-Remonstrantie beskryf word, is waarskynlik deur Festus Hommius (1576-1642) geformuleer (Pont 1994:89). Die Schriftelijke Conferentie loop op 29 November 1611 ten einde toe die dokumentasie aan die State oorhandig is. Die volgende dag, 30 November 1611, is die adviese voorgelees (Verboom 2005:149). Dit was 'n eerlike poging om 'n beter begrip tussen die twee partye te bevorder. As gevolg van die Remonstrantie en in die lig van die ContraRemonstrantie is ten minste tot ' $n$ heldere formulering van die Status quaestionis gevorder. Uiteindelik het die Conferentie nie die kerk gehelp om uit sy impasse te kom nie. Die vertroue van die Contra-Remonstrante in die owerheid daal tot 'n minimum. Dit sou in almal se belang wees as die Staten van Holland die Staten-Generaal opdrag sou gee om so gou moontlik 'n sinodale vergadering byeen te roep (Verboom 2005:158-159).

As 'n laaste poging word na die sameroeping van Wtenbogaert en Hommius deur Willem Lodewyk (15601620) van Nassau (stadhouer van Friesland), 'n tweede Schriftelijke Conferentie op 27 en 28 Februarie 1613 in Delft gehou om 'n weg van vrede uit te dink en aan die kerk vir goedkeuring voor te lê. Ook hierdie poging misluk, aangesien Wtenbogaert die Contra-Remonstrante se geskrifte as 'n persoonlike aanval beleef het waaraan die Staten niks gedoen het nie (Verboom 2005:173, 181, 188).
As gevolg van die toenemende onenigheid op vele plekke, poog Van Oldenbarnevelt om Koning Jacobus I (1566-1625) van Engeland (regerende monarg vanaf 1603 tot 1625), te nader om by die Staten-Generaal en die Staten van Holland daarop aan te dring om 'een edict van tolerantie' uit te vaardig in 'n poging om die toenemende konflik aan bande te lê. Dit gebeur in 1614 in die Staten van Holland se Resolutie tot de vrede der kercken (Verboom 2005:181). Jacobus I maak beswaar teen die benoeming van Vorstius as hoogleraar in Leiden (Van 't Spijker 1987a:36) en is teen die hou van 'n sinode in Utrecht, in plaas van Dordt gekant. Hy tree volgens 'n eie bybelse geloof op, wat ruimte vir sy biskoplike voorkeure sou maak. Hy koester ook die gedagte van 'n Europese protestantse kerk waarin die Anglikaanse Kerk 'n rol kon speel (Van 't Spijker 1987a:17-18, 56; 1987b:95).

Aan die einde van 1616 kom Van Oldenbarnevelt met 'n nuwe plan na vore, naamlik om stadsbestuurders te magtig om waardgelders (soldate) in diens te neem om die oproer in hulle gebied in die kiem te smoor - iets wat wesenlik teen die Contra-Remonstrante gemik was. Dit sou as die Scherpe Resolutie bekend staan en is op 4 Augustus 1617 uitgevaardig (Verboom 2005:183).

Dit lei tot die finale breuk tussen Maurits en Van Oldenbarnevelt, veral toe Maurits openlik vir die ContraRemonstrante kies en hulle erediens op 23 Julie 1617 in die Kloosterkerk in Den Haag bywoon. Daarmee sluit hy openlik by die Contra-Remonstrante aan en word deur sy rang en amp hulle aanvoerder. Maurits kom in beweging en hef die aanstelling van alle soldate op en dreig dat enige weerstand met teregstelling beantwoord sou word. Daarmee saam word Van Oldenbarnevelt, Hugo de Groot, Hoogerbeets en Gillis van Ledenberg gearresteer.

Op 4 Oktober 1617 besluit die Staten-Generaal met 'n meerderheidstem om 'n nasionale sinode byeen te roep (Verboom 2005:185).

\section{Die heersende denkklimaat en faktore wat direk en indirek 'n invloed op die Sinode van Dordt uitoefen}

Dordt kan nie los van sy histories-politieke omstandighede verstaan word nie. Na die Konvent van Wezel (1568) en die Sinode van Emden (1571) wat buite die grense van Nederland plaasvind aangesien die kerk onder die kruis verkeer het, kom die vryheid in 1572. Die vryheid het egter nie beteken dat die kerk in die lig van die Woord volkome vry sou wees van die gesag van die owerheid nie. Owerhede het oor die algemeen 'weinig anders gedaan dan matigen (modereren) en vertragen (retarderen)'. Die probleme in die sinode staan in die verlenging van die stryd wat die sinode voorafgegaan het. 'Zou de orde van de kerk een kerkelijke zijn of zou haar bestuur dat van een staatskerkorde zijn' - twee sienings wat moeilik met mekaar versoenbaar was. Daarnaas was die 
binding aan die belydenis ook 'n aangeleentheid wat spanning veroorsaak het (Van 't Spijker 1987a:18).

Die spanning wat in die aanloop tot die Dordtse Sinode geheers het, is aanwysbaar sedert die Sinode van Emden in 1571. Dit was in die kritiek van Dirck Volkertsz Coornhert (1522-1590) gesetel oor die erfsonde met verwysing na die Heidelbergse Kategismus. Sy kritiek was ook oor die leer van die verkiesing soos deur Calvyn en Beza gesien is. Hy word deur Caspar Coolhaes (1536-1615) ondersteun wat oortuig was dat die owerheid seggenskap in kerklike sake toekom. Hubert Duifhuis (1531-1581) meen dat wanneer die owerheid gereformeerd was, die magistraat voldoende is om in die plek van 'n kerkraad op te tree (Van 't Spijker 1987a:29-31). Kritiek wentel derhalwe om die belydenisskrifte en die kerklike orde, met die gevolglike inspraak van die owerheid in kerklike aangeleenthede.

In verband met Calvyn en Beza moet ook op die invloed van die Gereformeerde Ortodoksie gewys word, waarvan 'n sterk lyn aan te wys is van Genève na Dordt en name soos Beza, Vermigli en Zanchius dan ter sprake kom (Van 't Spijker 1991:142). Eenvoudig gestel het dit daarop uitgeloop dat reformatoriese grondbegrippe tog 'n ietwat ander betekenis gekry het. Daar was ' $n$ poging tot ' $n$ rasionele waarheidsisteem wat op logiese gronde verdedigbaar sou wees. Hierin het die metodiek van die wysbegeerte van Aristoteles 'n wesenlike rol gespeel (vgl. Graafland 1987a:4-5). Die Skrif is tot 'n geheel van tesisse vervorm waarop suiwere en onfeilbare afleidings gemaak kan word wat nie dwaal nie. Die persoonlike verbondenheid met Jesus Christus deur die Heilige Gees moes plek maak vir die waarheid van die Skrif. 'Het was veel meer de retorische en de logische redenaar, die de moeilikste zaken met zijn syllogismen begrijplijk kon maken en daarvoor de stellingen leverde ...' (Van 't Spijker 1991:141).

Beza, Calvyn se opvolger en ook tydgenoot, word selfs as een van die belangrikste oriëntasiepunte van die latere ortodoksie beskou. Die wesenlike verandering volg waarskynlik uit die feit dat Beza die uitverkiesing aan die begin plaas en aan die Godsleer bind, terwyl Calvyn die uitverkiesing aan die einde van die Pneumatologie laat staan (Graafland 1987b:53). Pont (1994:127) wys daarop dat Beza na die Roomse Konsilie van Trente (1545-1565) in 'n moeilike posisie was en oordeel dat, ter verdediging van die Skolastieke teologie van Thomas Aquinas wat op die Aristoteliese logika gebou is, dit juis die belangrikste wapen was ter verdediging van Aquinas wat deur die Konsilie tot die belangrikste Rooms-Katolieke teoloog van alle tye verklaar is. Dat die spore van hierdie tyd ook op die Dordtse Sinode en sy debatte aanwysbaar sou wees, was te verwagte vanweë die uitkringende invloed van die denkwyse wat in verskillende woordvoerders ter sprake gekom het (Krop 2011:50, 55).

Dit is nie moontlik om alles in 'n sluitende logiese sisteem in te forseer nie. Die evangelie kan nie deur die logika en reglynigheid oorwoeker word nie. Van Ruler (1971) stel dat:

Ook wanneer de helle zon van de dubbele predestinatie alles doorschroeit, de hele historische Christus, de hele bemiddeling van het heil in de traditie, de hele uitwendigheid van het evangelie en de kerk, de hele subjektiviteit van de mens. Er blijft maar één ding over: de eeuwige raad. (bl. 106)

Naas die kerklike situasie was die politieke spanning, veral tussen persone soos Van Oldenbarnevelt (verteenwoordiger van die republikeinse beginsel en ondersteuner van die Remonstrante) en prins Maurits (wat met 'n beroep op sy vader, prins Willem van Oranje, 'n keuse vir die ContraRemonstrante gemaak het; Goudriaan \& Lieburg 2011:X). Hierdeur word die klimaat geskep om 'n sinode byeen te roep, maar dit was juis die gereformeerdes wat hulle teen staatsinmenging verset het (Verboom 2005:75).

Daar het dus 'n persoonlike stryd tussen Van Oldenbarnevelt en Maurits gewoed wat hulle elkeen by een van die partye geskaar en uiteindelik 'n botsing tussen kerk en staat onvermydelik gemaak het as gevolg van weerstand teen staatsinmenging in kerklike aangeleenthede. Maurits maak gebruik van sy mag en persoonlike aansien en laat Van Oldenbarnevelt arresteer, verhoor (Van 't Spijker 1987a:55) en op 13 Mei 1619 in Den Haag teregstel (Pont 1994:98; vgl. Spaans 2011:340). Dit was ook die dag waarop die 155e sitting van die Sinode 'n aanvang geneem het nadat die buitelandse teoloë die Sinode op 9 Mei 1619 tydens die 154e sitting verlaat het (Kuyper 1899:95-96). In die gedrukte vonnis deur 24 regters word die begrip landsverraad nie gebruik nie, maar wel bedoel. Offisieel word Van Oldenbarnevelt tereggestel vanweë 'subversie van religie en politiek' en 'perturbatie van de gemene (algemene) rust'. Wtenbogaert vlug na Antwerpen en Hugo de Groot is tot lewenslange gevangeskap in die 'staatsgevangenis slot Loevestein' gevonnis (Selderhuis 2006:426).

\section{Voorlopige opmerkings}

Kohlbrugge (1803-1875) het daarop gewys dat die Sinode die teologiese en geestelike kern van die geskil links gelaat het, deur nie juis op die bestryding van Arminius se regverdigingsleer in te gaan nie. Graafland (1987b) meen:

Een van de oorzaken daarvan is, dat de Dordtse Vaderen door het (opzettelijk) verzwijgen van de rechtvaardigingsleer door Arminius en in zijn spoor door de Remonstranten in hun Remonstrantie zich om de tuin hebben laten leiden. (bl. 122)

Graafland (1987b:121) dui aan dat die regverdigingsleer nouliks in die Dordtse Leerreëls ter sprake kom, terwyl dit wesenlik vir die verhouding tussen Arminius en die gereformeerde geloofsdenke van hierdie tyd is. Dit is begryplik waarom die Arminiaanse regverdigingsleer nie in die Dordtse Leerreëls bespreek is nie, aangesien dit nie in die Remonstrantie van 1611 voorkom nie en die Sinode as weerlegging slegs teen die inhoud reageer (vgl. Van Zyl 2004:129).

Dit is verdienstelik om aan die hand van Graafland verder na Arminius se regverdigingsleer te verwys. Indien iemand se skuld deur iemand anders as die werklike skuldenaar betaal word, kom dit nie op kwytskelding neer nie. Indien iemand egter sy skuld gedeeltelik afgelos het en die res hom dan 
kwytgeskeld word, kom toerekening dan eers ter sprake en dien die eie betaling as kwytskelding van die geheel. Toegepas op die verhouding tussen Christus en gelowiges sou geloof geen doel dien as Christus gelowiges sonder meer volkome geregverdig het nie. Vir hom lewer geloof 'n bydraende gewig sodat iemand uiteindelik geheel regverdig geag word op grond van sy geloof. Christus lewer dus 'n bydraende geregtigheid wat deur die ontvanger se geloof volkome word, aangesien 'de gerechtigheid van Christus slechts de mogelijkheid ertoe opent om de geloofsdaad van de mens door God tot volkomen gerechtigheid te rekenen, op grond waarvan Hij de zondaar rechtvaardigt' (Graafland 1987b:125; vgl. Pont 1994:87).

Aangesien Gomarus, die Contra-Remonstrante en die Dordtse Sinode die geskil deur die Remonstrante laat omlyn, voer die geskille oor die uitverkiesing die botoon en word die regverdigingsleer onderbeklemtoon. Daar is dus ' $n$ ondertoon van wat 'n korrelatiewe samewerking tussen God en mens genoem kan word en wat die reformatoriese aksioma van sola gratia ondermyn. Die geregtigheid van die mens is sodoende ' $n$ geregtigheid wat in die mens self te vind is en op elemente van 'n Roomse regverdigingsleer dui. Dit herinner sterk aan die analogia entis-debat wat veral deur Barth (1958:90) afgekeur is (vgl. Denzinger 2012:605; Van Niftrik 1949:242-246).

Die kern van die reformatoriese regverdigingsleer het daarop neergekom, dat 'wij alleen kunnen leven en bestaan voor God dankzij de vreemde gerechtigheid van Christus en op geen enkele wijze dankzij onze eigen gerechtigheid, hoe deze ook verstaan wordt' (Graafland 1987b:125).

\section{Die samestelling en gesag van die Dordtse Sinode}

Die Sinode van Dordrecht het in Dordrecht byeengekom vanaf 13 November 1618 tot 29 Mei 1619 (Doornbos 1967:3840; vgl. Kuyper 1899:96). Die sinode is uit 37 predikante en 19 ouderlinge saamgestel, asook 25 buitelandse afgevaardigdes uit Engeland, die Palts, Hessen, Genève, Switserland, Bremen, Emden, Wetteravië en Nassau (Verboom 2005:201; vgl. Van 't Spijker 1987b:96-97). Verder was daar ook 18 verteenwoordigers van die Staten-Generaal afgevaardig wat moes toesien dat orde gehandhaaf en slegs kerklike sake behandel sou word, asook 'n aantal professore, naamlik Episcopius (deel van die Remonstrantse afvaardiging), Sibrandus Lubbertus, Antonius Thysius en Franciskus Gomarus teenwoordig (Van 't Spijker 1987b:100). In die sinode verskyn ook 15 predikante uit Remonstrantse geledere wat eers op 6 Desember 1618, tydens die 22e sitting, ter vergadering gekom het (Donner \& Van den Hoorn s.a.:48). Verrigtinge van die sinode tussen die opening en die binnekoms van die Remonstrante staan bekend as die PreActa van die sinode waartydens aangeleenthede soos Bybelvertaling, onderwys in die kategismus, doop van heidenkinders, voorbereiding van teologiese kandidate en die druk en verspreiding van boeke na aanleiding van verskillende voorgelegde gravamina hanteer is (vgl. Kaajan 1914). Die sinodale verrigtinge, bekend as die Post-Acta, is die gedeelte nadat die buitelandse teoloë tydens die $154 \mathrm{e}$ sitting op 9 Mei 1619 vertrek het en die sinode se verrigtinge op 13 Mei 1619 met die 155e sitting voortgegaan het (Donner \& Van den Hoorns.a.:935) met diehersiening van diebelydenisskrifte asook verskeie gravamina wat ter tafel geneem is (vgl. Kuyper 1899). Die Dordtse sinode strek dus oor 180 sittings (vgl. Goudriaan \& Lieberg 2011:XI).

Minder bekend is die drie weke lange periode gedurende Maart tot April 1619 waartydens die Sinode besig was met die formulering van die Leerreëls en hoedanig die proses verloop het. Meer as 100 argivale dokumente in die biblioteke van Nederland, Switserland en Engeland het behoue gebly. Hierin word ook die belangrike rol van die voorsitter, Bogerman, in die formulering van die artikels blootgelê (vgl. Sinnema 2011a:291-292).

Professor Simon Episcopius (1583-1643), een van die opvolgers van Arminius en Gomarus in Leiden (Van 't Spijker 1987a:36), was die belangrikste woordvoerder van die Remonstrante en het in sy rede gepoog om die aanwesiges te oortuig dat die sinode in die vorm van 'n konferensie moes verloop, eerder as 'n sinode waar die kerk besluit op grond van die Skrif en die belydenisskrifte van die kerk. In hierdie verband het die politieke afgevaardigdes 'n handige bydrae gelewer deur in te gryp, en in weerwil van die Remonstrante se vertragingstaktiek (Pont 1994:99), te bepaal dat die vergadering op die basis van 'n sinodale vergadering sou verloop wat bindende besluite kon neem na beoordeling van die voorlegging van die Remonstrante (Van 't Spijker 1987b:102-105; vgl. Doornbos 1967:66-67; Hoeksema 1980:26-27).

\section{Die inhoud van die Leerreëls van nader beskou}

In sommige kringe word die Leerreëls negatief beleef en die vraag word gestel of die Leerreëls enigsins deel van die kerklike belydenisskrifte moet vorm. Waarskynlik is die kern van sodanige besware in die Jakob-Esau voorbeeld (Rom 9:13) geleë, waaruit die mening gevorm word dat predestinasie die botoon voer asof God deur 'n ewige en onveranderlike dekreet, ongeag, sommige uitverkies en ander verwerp het. Met ander woorde, 'as ons sou dink dat God, voor die grondlegging van die wêreld, die uitverkiesing as 'n ewig onveranderlike besluit daargestel het en nou funksioneer hierdie besluit as 't ware outomaties: ongeag Christus, ongeag die verkondiging van die evangelie, ongeag die ontferming en genade van God' (Pont 1994:105). Sodanige siening het tot gevolg gehad dat die Leerreëls met minder entoesiasme bejeën is en derhalwe ook minder in kerklike geledere bekend is (vgl. Van Wyk (2015:1).

Wanneer die Dordtse Leerreëls so beskou word, is daar weinig ruimte vir 'n Christologiese klem tot troos vir die kerk en die gelowiges. Hiermee hang ook die vraag saam of die 
Leerreëls supralapsaries of infralapsaries beskou moet word. (Eenvoudig gestel word die sondeval enersyds voor die skepping geplaas - dus supralapsaries en andersyds na die skepping in verband met die val van Adam - dus infralapsaries. Dit was veral Dontelock wat die infralapsariese standpunt beklemtoon het. Daar moet steeds in gedagte gehou word dat die Sinode op die inhoud van die Remonstrante se verweerskrif reageer en dit loop daarop uit dat die regverdiging deur die geloof alleen, in samehang met die uitverkiesing, nie behandel word nie, maar dat die wedergeboorte op die voorgrond geplaas is (Pont 1994:110). Dit is egter duidelik dat Dordt poog om die indruk van enige vorm van menslike medeverantwoordelikheid of medeseggenskap by die uitverkiesing of die ontvangs van die heil te voorkom. Uitverkiesing is 'n uitverkiesing in Jesus Christus.

\section{Die Dordtse Leerreëls \\ Hoofstuk 1}

\section{Goddelike verkiesing en verwerping (Artikels 1-18)}

Reg aan die begin van die Leerreëls word die sondeval van die mens wat in Adam plaasgevind het (infralapsaries, dus; Van Zyl 2004:130) gestel (Rom 3:19, 23; 6:23) teenoor die liefde van God wat in Christus tot uiting kom as 'n liefde, nie net vir die uitverkorenes nie, maar vir die hele wêreld (Joh 3:16). Artikel 1 en 2 is met 'n maar verbind, wat beteken dat die tweede voorrang geniet. Dit is opvallend dat die sola fide ook beklemtoon word en dit beteken dat gelowiges in Christus behou word en nie verlore gaan nie (Verboom 2005:212; vgl. ook Hoeksema 1980:123).

In artikel 3 word beklemtoon dat geloof 'n geskenk van God is wat Hy uit louter goedheid skenk aan wie Hy wil en wanneer Hy wil. Tegelyk met die goedheid van God word ook sy vryheid beklemtoon om verkondigers te stuur aan wie en wanneer Hy wil. Opnuut word die twee werklikhede wat in artikel 4 genoem word, verbind met 'n 'maar'. Die toorn van God is op hulle wat die evangelie nie glo nie, maar hulle wat Jesus Christus as Verlosser aanneem, ontvang die ewige lewe.

Artikel 5 stel dat die oorsaak of die skuld van sommige mense se ongeloof nie by God te vind is nie, maar by die mens self. Hiermee word die verwyt van die Remonstrante dat God die outeur van die sonde is, afgewys. God is die outeur van die geloof deur Jesus Christus (Verboom 2005:213).

Miskien dra artikel 6 daartoe by dat sommiges die Leerreëls krities as 'n dubbele predestinasie bejeën, naamlik dat sommiges uitverkies is en ander nie. Verkiesing geskied egter nie op grond van 'n bepaalde menslike eienskap nie, maar volg op God se raadsbesluit. God maak 'n keuse uit mense wat almal ewe verlore is en buig die verharde harte om tot geloof volgens sy regverdige oordeel. Die bedoeling is dus dat verlore mense glo en die redding ontvang. Dit word nooit 'n verdienste nie, net so min as wat ongeloof as 'n onreg van God gesien moet word. Verboom (2005:214) wys daarop dat die leer nie verdraai moet word tot die eie verderf nie. Dit kom wesenlik daarop neer dat die eer van God aangetas word. Menslike logika moet nie tuis word in die gesprek oor die groot dade van God nie, want die vraag is of die Bybel regtig só reglynig oor uitverkiesing en verwerping handel, al dan nie. Verboom (2005:214) voel aan dat hier 'n 'causale redeneertrant' aan die orde is eerder as 'n nasegging van die Skrif. Die verwerping wat in die dubbele predestinasie ter sprake kom, moet met besondere bybelse uitsprake in gedagte in die hermeneutiese konteks beskou word (vgl. Joh 3:16; Ef 1:4; vgl. ook Graafland 1987b:138-142; Van Zyl 2004:131).

Artikel 7 dui op die infralapsariese standpunt van die Leerreëls (Hoeksema 1980:163-165). God se keuse is vir mense wat in sonde geval het, waardeur die supralapsariese standpunt afgewys word. Die Remonstrante se siening dat Christus die fondament van die verkiesing is, word gekorrigeer wanneer aangedui word dat Christus die Middelaar en Hoof en derhalwe die fondament van die saligheid is. God het mense in Christus nog voor die skepping uitverkies, as ' $n$ uitverkiesing in Christus wat nie buite Christus neerkom op 'n onchristelike verkiesing of verwerping nie. Die ietwat eksklusiwistiese formulering aan die begin dat God 'n sekere aantal mense uitverkies het, moet uit die res van die formulering verstaan en geïnterpreteer word as 'n uitverkiesing in Christus.

Artikel 8 grens af teen die Remonstrante se siening dat die verkiesing veelvoudig is en op ' $n$ algemene en ' $n$ besondere verkiesing neerkom (Verboom 2005:216). Algemeen is voorlopig en die besondere verkiesing realiseer in 'n volhardende geloof. Iets skemer deur van die Remonstrantse korrelatiewe verlossingsleer, naamlik dat die mens deur sy volhardende geloof die goddelike keuse effektief kan maak.

In artikel 9 word opnuut standpunt teen die Remonstrante se siening ingeneem, naamlik dat God besluit het om die mens salig te verklaar op grond van die mens se geloof. Die mens beskik nie oor enige kwaliteit wat tot God se soewereine genade kan bydra nie. Die mens word nie as gevolg van sy geloof uitverkies nie, maar uitverkies tot geloof en gehoorsaamheid. Geloof volg op die uitverkiesing en nie andersom nie. Daarom is uitverkiesing ' $n$ fontein van alle saligheid. Enige menslike kwaliteit op grond waarvan God se verkiesing geskoei word, tas God se genade aan en lei tot voortdurende onsekerheid waardeur aan die sola fide tekort gedoen word (vgl. Van Zyl 2004:132). Artikel 10 sluit daarby aan met die beklemtoning dat die uitverkiesing niks anders is as die welbehae van God nie. Mense word verkies omdat God wil. Dit gaan nie om die teenstelling tussen verdienste en genade nie, maar om God se wil teenoor dít wat mense wil (Verboom 2005:217).

Die leer van die uitverkiesing staan sentraal (artikel 11) en is onveranderlik (Hoeksema 1980:193). Dit is 'n voorbeeld dat die Sinode nie simmetries oor verkiesing en verwerping 
gedink het nie. God se verkiesing word nie met verwerping in balans gebring nie, dit word daarvan afgelei wanneer God se dade logies beredeneer word.

In artikel 12 word gereageer teen die Remonstrante se mening dat die Contra-Remonstrante se siening oor die uitverkiesing mense onseker maak, aangesien volgens hulle, sekerheid slegs moontlik is wanneer gelowiges ' $n$ bydrae daartoe lewer. Sekerheid is egter nie die gevolg van 'n deurgronding van die verborgenhede van die Skrif nie, maar 'n belewenis van die onfeilbare vrugte van die uitverkiesing soos 'n ware geloof, kinderlike vrees vir God en dies meer (2 Kor 13:5; vgl. Hoeksema 1980:203-207). Die formulering herinner aan die praktiese sillogisme (vgl. Weber 1962:402-403) wat in die Heidelbergse Kategismus, vraag en antwoord 86, aangetref word waar geloofsekerheid uit die vrugte van die geloof volg, en die naaste selfs deur 'n godvresende lewe vir Christus gewen kan word. Verboom (2005:219) meen dat hierin 'n verskuiwing van die belydenisskrifte se objektiewe geloofsekerheid in die beloftes van God plaasvind, na 'n subjektiewe sekerheid wat in die waarneming van sekere kenmerke van gelowiges berus. Hierdie formulering sou dus krities beskou kan word, maar kom ook in die HK voor, en wat moontlik in die agtergrond van die finale formulering gestaan het.

Artikel 13 grens af teen die Remonstrante se siening dat die uitverkiesing soos gestel deur die Contra-Remonstrante, aanleiding tot 'n goddelose en sorgelose lewe kan gee, waarskynlik omdat verkiesing volledig uit genade gebeur sonder 'n menslike byverdienste. Dit herinner aan die Roomse kritiek op die genadeleer van die Reformasie (Verboom 2005:220), want dit is onmoontlik om in die geloof te leef sonder enige vrugte wat daarby pas (vgl. HK 64). Die masker glip uiteindelik: ware geloof en alles wat daarmee saamhang deurkruis alle menslike eiegeregtigheid. Geloof is nie toneelspel nie.

In artikel 14 word uitverkiesing as 'n deel van die kerklike leer gesien waaroor nie geswyg kan word nie, maar genuanseerd, oordeelkundig, met gelowige eerbied en heilige ontsag nagedink moet word, sonder om God onder die maatstaf van menslike kennis en logika te plaas. Dit val op dat niks van verwerping gemeld word nie.

In artikel 15 word die moontlikheid van verwerping vermeld. Dit staan nie parallel aan verkiesing nie, maar volg nadat daar oor uitverkiesing gehandel is. Verwerping was volgens die Remonstrante 'n kwesbare steen in die gebou van die predestinasieleer van Dordt. Verwerping kom daarop neer dat God sommige verbygaan (infralapsaries) waarvoor daar geen verklaring is nie; dit is sy wil. Verwerping is nie die doel in sigself nie, maar staan in diens van die verkiesing. 'n Supralapsariese siening sou God die outeur van die sonde maak, maar die mens het self en vrywillig vir die sonde gekies. Indien iemand verlore gaan, is dit sy eie toedoen en nie op grond van 'n vooruitgesiene ongeloof nie.
Volgens Verboom moet opgemerk word dat volgens Dordt, God tog besluit het om die saligmakende geloof en genade van bekering van sommige mense te weerhou. Dit gaan nie net om genade nie, maar om verkiesing of verwerping. Iemand word nie verwerp vanweë ongeloof nie, maar tót ongeloof. Verboom meen dat dit een van die onbeantwoorde vrae aan Dordt is. Hy (2005) merk op:

Gods verkiezing wil zeggen dat Gods keus altijd aan onze keus voorafgaat. Van Gods verwerping moet gezegd worden dat Gods keus ná onze keus komt. ... God houdt de verharding van de mens heel lang vol, maar er is een grens. Als die grens bereikt is, reageert God met zijn verwerping. Zó is zijn eeuwig besluit. (bl. 221)

In artikel 16 klink die pastorale toonaard van die Sinode wat vertroostend wil wees en almal wil huisves, al word die heilsmiddele sonder enige onmiddellike gevolge gebruik (vgl. Mat 11:28; 12:20). Dit is nog meer vertroostend en pastoraal wanneer in artikel 17 na die genadeverbond verwys word (vgl. Hoeksema 1980:279). Dit kan as leemte gesien word dat die Leerreëls nie meer na die genadeverbond verwys nie, want daardeur word uitverkiesing en verbond in ewewig geplaas. Die eerste hoofstuk word met die verwerping van alle weerstand teen die leer van die uitverkiesing afgesluit en met ' $n$ beroep op Romeine 11:33-36 om te vermaan dat nie gepoog moet word om op die regterstoel van God te wil sit nie (artikel 18; vgl. Hoeksema 1980:285).

\section{Hoofstuk 2}

\section{Die dood van Christus en die verlossing van die mense deur sy dood (Artikels 1-9)}

God is nie alleen barmhartig nie, maar ook regverdig. Die sonde eis dat die sondaar nie alleen aan tydelik strawwe onderworpe moet wees nie, maar ook aan ewige strawwe na liggaam en siel. Alleen indien aan die geregtigheid van God op juridiese gronde voldoen is, kan aan die straf ontkom word. Die sinode verwoord hier die reformatoriese regverdigingsleer in ' $n$ tipies Anselmiaanse sin (artikel 1). Die enigste manier is deur Christus wat aan die geregtigheid van God voldoen het, aangesien 'n mens nie kan voldoen nie, want die geregtigheid eis dat daar vir die sonde betaal moet word (artikel 2; vgl. Confessio Augustana, artikel 4 en die Nederlandse Geloofsbelydenis, artikels 20 en 21). Artikel 3 beskryf die dood van die Seun van God as die enigste en volmaakte offer, voldoende vir die sondes, in staat om die hele wêreld te versoen. Die versoening is in Christus seker, want Hy was volledig mens om die straf te kan dra. Hy is ook volledig God om die straf weg te dra. ' $n$ Vaster fondament vir die heil bestaan nie (artikel 4; vgl. Hoeksema 1980:348).

Artikel 5 beklemtoon dat die uitverkiesing en die evangelie nie met mekaar op 'n gespanne voet verkeer nie. Die verkondiging van die evangelie gaan aan predestinasie vooraf en moet in die geloof gestalte vind. Dit is insiggewend dat die belofte sonder die skadu van verwerping hier gestel word. Dit is ' $n$ aanduiding van die feit dat die uitverkiesing in die Leerreëls swaarder weeg as die verwerping. God stuur 
die evangelie sonder voorbehoud met die eis tot bekering en geloof. Verboom (2005:228) sien hierdie artikel as 'n toonbeeld van die kosbare reformatoriese erfgoed (vgl. Hoeksema 1980:349)

Artikel 6 stel die feit dat baie wat deur die evangelie geroep is, hulle nie bekeer of in Christus glo nie. Die Sinode bevestig dat dit nie aan God te wyte is dat diegene nie uitverkies is nie. As mense verlore gaan, is dit hulle eie skuld. Geloof is ' $n$ weldaad wat uit die genade van God spruit wat van ewigheid in Christus gegee is (artikel 7; vgl. Hoeksema 1980:369).

Artikel 8 volg as 'n verklaring van artikel 7 waarin gestel word dat die regverdigende geloof tog maar tot die uitverkorenes beperk is. Verboom (2005:230) som die verskil tussen die twee strydende partye soos volg op: die Remonstrante leer dat Christus vir almal gesterf het, maar slegs die gelowiges deel in die vrug daarvan. Die ContraRemonstrante leer dat Christus se offer vir die hele wêreld voldoende is, maar slegs die uitverkorenes deel daarin. Beide partye soek 'n verbinding tussen die universele en die partikuliere gegewens oor die heil in die Skrif. Die Remonstrante vra hoe dit moontlik is dat Christus sy lewe vir elkeen gee, terwyl nie almal die vrug daarvan ontvang nie, terwyl die Contra-Remonstrante vra hoe dit moontlik is dat elkeen die aanbod van genade ontvang, terwyl tog net die uitverkorenes die inhoud daarvan ontvang. Daar is waarskynlik nie ' $n$ afdoende bewys hiervoor nie en dit is teenproduktief om daaroor 'n logiese, skriftuurlike antwoord te wil vind (vgl. Hoeksema 1980:371-375).

In artikel 9 word opnuut na God se liefde vir die uitverkorenes verwys in die beeld van die bruid en die Bruidegom. Dit is van betekenis dat gestel word dat die uitvoering van die raadsbesluit van die begin van die wêreld tót vandag gebeur, sodat die uitverkorenes op die regte tyd in een liggaam vergader sal word. Die HK kyk vanuit die kerk na die uitverkiesing (vgl. Hoeksema 1980:377), terwyl die Leerreëls van die uitverkiesing redeneer na die kerk toe. Die HK meen dat verbondenheid aan die kerk op uitverkiesing dui, terwyl die Leerreëls stel dat uitverkiesing deelname aan die kerk veronderstel. Die HK vertrek van geloof na uitverkiesing, terwyl die Leerreëls vanuit die uitverkiesing tot geloof beweeg (Verboom 2005:231).

\section{Hoofstukke 3 en 4}

\section{Die verdorwenheid van die mens, sy bekering tot God en die wyse waarop dit plaasvind (Artikels 1-17)}

Die Leerreëls beklemtoon die historiese werklikheid van die sondeval wat nie aan die mens opgelê is nie, maar wat vanweë die duiwel en uit eie vrye wil gebeur het (art. 1). Die leer oor die erfsonde word hier ter sprake gebring. Dit kom daarop neer dat mense nie sondig is vanweë navolging nie (Pelagius), maar erflik belas is (vgl. Hoeksema 1980:445). Mense is sondig tensy hulle weer gebore word deur die genade wat deur die Heilige Gees geskenk word (art. 2 en 3; vgl. Hoeksema 1980:451). Ten spyte van die sondeval het daar tog 'n bietjie van die lig oorgebly soos dit ook deur Calvyn (1986:383-391) en in die NGB (Art. 14) gestel word. Hiermee het die mens tog ' $n$ besef van die onderskeid tussen goed en kwaad behou. Dit beteken nie dat die mens oor 'n aangebore aanknopingspunt tot geestelike herstel beskik nie. Desondanks kan hy hom nie verontskuldig nie (art. 4; Hoeksema 1980:454; Verboom 2005:234). Die Wet van God ontbloot die mens se sondige dade, maar genees hom nie, aangesien die mens nie in staat is om uit eie vermoë die saligmakende genade te verkry nie (art. 5). Dit waartoe die mens nie in staat is nie, word deur God deur sy Gees en Woord bewerk, naamlik die bediening van die versoening (art. 6; Hoeksema 1980:475). God het die grense tussen Israel en die volkere met die koms van Christus deurbreek. Dit is nie moontlik om God se dade, wat in sy vrye welbehae en onverdiende liefde geskied, volkome te begryp nie, behalwe om sy dade met nederige en dankbare harte te erken (art. 7).

In artikel 8 word beklemtoon dat almal geroep is, daarom word die evangelie aan almal verkondig. Die Leerreëls maak geen onderskeid tussen die inwendige- en die uitwendige roeping nie soos dit later in die Gereformeerde Protestantisme bekend geraak het nie (Verboom 2005:236). In artikel 9 word met verwysing na die gelykenis van die saaier beklemtoon dat diegene wat klaarblyklik nie geroepe voel nie, die skuld nie op God kan plaas nie, want die probleem setel nie in die saaier of die saad nie, maar in die akker. Daarenteen kan niemand wat deur die evangelie geroep en bekeer is, onder die indruk verkeer dat dit in eie krag plaasgevind het nie; dit moet aan God toegeskryf word. Mense het sedert die sondeval nie meer 'n vrye wil (Pelagius) nie, daarom geskied dit omdat God dit wil, want Hy het hulle van ewigheid af in Christus uitverkies (art. 10).

God se handewerk aan die mens is omvattend en skenk aan die mens die wedergeboorte en dring sodoende deur tot die binneste dele van die mens (by wyse van spreke). Wedergeboorte is 'n nuutskepping soos die opwekking uit die dood en die lewendmaking waarvan die Skrif getuig. Die mens se wil is aan die kwaad gebonde, maar dit word nou tot die goeie in die mens omskep - die mens wat passief is omdat God dit in die mens bewerk, maar wel sonder die mens (Hoeksema 1980:521). Eers daarna kom die vernuwende werk van God in die mens ter sprake wanneer die mens tot bekering kom en die evangelie glo. Die NGB en die HK leer dat die mens deur geloof wedergebore word, terwyl die Leerreëls stel dat die mens deur die wedergeboorte tot geloof gebring word. Verboom (2005:239) stel dat die Christologie in die Leerreëls deur die predestinasie beheers word, asook deur die Pneumatologie (art. 11 en 12). Artikel 13 is 'n tipiese handreiking om moedig te bly en te aanvaar dat die onbegryplike tog 'n realiteit is en om dit van harte te glo. Geloof is 'n gawe van God wat nie net die moontlikheid nie, maar ook die geloof self effektief maak. Die wil om te glo én die geloof self word in die mens tot stand gebring (art. 14). Iemand het die genade tot wedergeboorte ontvang, of het dit nie ontvang nie. Weereens moet die belewenis daarvan nie 
tot meerderwaardigheid lei nie, net so min as wat ander wat dit klaarblyklik nie beleef nie, minderwaardig behandel moet word nie (art. 15; Hoeksema 1980:545).

Wedergeboorte geskied nie onder dwang nie, maar wek die vrywilligheid om die Here te dien. Daar is nie ' $n$ diskontinuïteit tussen die voor- en na-wedergebore mens nie, en daarom is wedergeboorte nie 'n menslike kwaliteit nie, maar die werk van die Heilige Gees (art. 16). Wedergeboorte bestaan in die midde van die gemeente en die heil moet nie van die heilsmiddele soos die bediening van die Woord, die amp en die tug losgemaak word nie (art. 17; Hoeksema 1980:565).

\section{Hoofstuk 5}

\section{Die volharding van die heiliges (Artikels 1-15)}

Verboom dui aan dat die hoogtepunt van die Leerreëls waarskynlik in die slothoofstuk gevind word, omdat die krag van die geloof wat deur die Sinode bely is, in die leer van die volharding van die gelowiges blyk - as keersy van die bewarende trou van God. Die leemte in die Remonstrante se siening blyk ook daarin dat 'het heil niet helemáál afhangt van Gods genade, wanneer genade niet voor de volle hondert procent genade meer is, dan is een mens nooit zeker van zijn heil' (Verboom 2005:244).

Ter aanvang word beklemtoon dat die wedergebore mens wel van die slawerny van die sonde verlos word, maar nie van die mag van die sonde nie (art. 1). Derhalwe vorder niemand deur onthouding en bekering tot ' $n$ bepaalde mate van sondeloosheid soos sommige Remonstrante nagehou het nie. Sonde wat nog die lewe van gelowiges ontsier, is nie as gevolg van ongeloof of onverskilligheid nie. Gelowiges moet hulle voortdurend tot God verootmoedig en stryd voer teen die sonde, terwyl hulle vurig na die volmaaktheid verlang om uiteindelik saam met die Lam van God in die hemel te regeer. Die Leerreëls volg hierin die argument soos vervat in die HK, vraag en antwoord 115 (art 2). Soos ook in die HK Sondag 52, word hier gestel dat niemand wat op eie krag steun teen die duiwel staande kan bly nie, maar God bewaar gelowiges tot die einde toe (art. 3; vgl. Hoeksema 1980:650). Gelowiges kan nie uit die genade uitval nie, maar kan wel in die sonde val. Daarom moet hulle voortdurend bid om nie in versoeking gelei te word nie. Daar bly steeds ruimte vir eie verantwoordelikheid en die moontlikheid dat God selfs sondes toelaat soos onder andere uit die lewens van Dawid en Petrus blyk (art. 4; Hoeksema 1980:655).

Die gevolge van die sonde plaas die verhouding met God onder druk, bedroef die Heilige Gees en verwond die eie gewete. Tog laat God sy vaderlike aangesig oor sondaars skyn wat tot inkeer kom na opregte berou (art. 5). Die Heilige Gees onttrek nie vanweë die uitverkiesing nie, ondanks die jammerlike sondeval waarin gelowiges beland. Sonde deurkruis nie die raad van God nie (art. 6). Behoud hang nie saam met die innerlike menslike vermoë nie, maar God behou die saad van die wedergeboorte. Met die saad van die wedergeboorte (Verboom 2005:246) word waarskynlik die Woord van God bedoel waardeur sondaars deur sy Woord en Gees tot bekering vernuwe word (vgl. Hoeksema 1980:684-685). Kennis van die sonde, verlossing en dankbaarheid herinner aan die bekende drieslag van die HK (art. 7).

God weerhou gelowiges vanweë sy genadige barmhartigheid daarvan om nie uit die geloof of die genade uit te val nie. God se raad verander nie, sy beloftes word nie verbreek nie, sy roeping word nie herroep nie, sy bewaring in Christus kan nie kragteloos gemaak word nie en die verseëling in die Heilige Gees word nie vernietig nie (art. 8; Hoeksema 1980:693-694). Artikel 9 is ' $n$ toonbeeld van geloofsekerheid wat nie subjektief in gelowiges setel nie, maar objektief in God gevind word na die maat van die geloof (vgl. HK vraag 54). Dit geskied nie buite die Woord van God om nie, maar is duidelik uit die geloof aan die beloftes van God wat in sy Woord geopenbaar is, uit die getuienis van die Heilige Gees, en uit 'n ernstige strewe na 'n goeie gewete en goeie werke (Hoeksema 1980:702-703). Goeie werke kan alleen as vrug van die geloof, as vertroue op God se beloftes, gesonde sekerheid bied (vgl. HK 86). 'Hence, it is the old and ever wonderful gospel: all of God, nothing of us! Soli Deo gloria!' (Hoeksema 1980:715; art. 10). Alhoewel gelowiges nie altyd geloofsekerheid ervaar nie, laat God nie toe dat gelowiges bo hulle vermoë versoek word nie. Hy gee saam met versoeking uitkoms en maak deur die Gees die sekerheid van volharding moontlik (art. 11).

Geloofsekerheid maak gelowiges nie argeloos of sorgeloos nie, maar spoor hulle juis tot standvastigheid in die belydenis van die waarheid aan, waaruit 'n blywende vreugde in God spruit. Inteendeel, 'the consideration of this benefit of the assurance of perseverance is an incentive to the serious and constant practice of gratitude and good works' (Hoeksema 1980:739; art. 12). Sekerheid kan beoefen word en neem toe, nie as die kwaliteit van 'n gelowige nie, maar as 'n gawe van God (art. 13). Die genadewerk van God word aan die verkondiging van die evangelie gebind en ook deur die gebruik van die sakramente bevestig (art. 14). Volharding en sekerheid van geloof vorm die murg van God se genade as 'n belewenis van die verhouding tussen die Bruidegom en die bruid.

Kan enige weerstand staande bly? Hoeksema (1980) antwoord:

Never! This very doctrine is the guarantee of it. ... the bride of Christ has always held this doctrine near, loved it tenderly, esteemed it a precious treasure, and defended it steadfastly. ... For God Himself Who preserves His church to the very end, the God against Whom neither counsel nor strength can prevail, shall see to it that His church, ... will continue to love and to defend this doctrine. The outcome is certain. (bl. 769)

Die Leerreëls eindig met ' $n$ trinitariese doksologie, Vader, Seun en Heilige Gees, eer en heerlikheid tot in ewigheid, Amen! (art. 15). 


\section{Die Dordtse Leerreëls: Inklusief of eksklusief?}

Die Dordtse Leerreëls vorm deel van die kerk se belydenisskrifte as 'n formulier van eenheid wat onder die quia-uitgangspunt gehandhaaf word, naamlik dat die inhoud van die belydenisskrif aanvaarbaar is omdat die leer wat hierin verwoord is in ooreenstemming met die Skrif is. Miskien is dit bruikbaar en dienlik om in die lig van Romeine 11:33-36 in ag te neem dat God nie in menslike, selfs gelowige denke ingedwing kan word nie. Per slot van rekening is God nie aan enigiemand iets verskuldig of vir sy voortbestaan afhanklik nie. God ís, sonder menslike toedoen of goedkeuring. Dit het Hy reeds aan Moses (Eks 3:14) bekend gemaak soos ook onder andere in die Johannese evangelie bevestig word.

Die besondere betekenis van die doop kan nie ongedaan gemaak word nie. Die dopeling is sondig as nageslag van Adam en derhalwe strafwaardig voor God (Rom 3:19, 23; 6:23). Die liefde van God is egter hierin geopenbaar dat Hy sy eniggebore Seun na die wêreld gestuur het, sodat die wat in Hom glo nie verlore sal gaan nie (Joh 3:16). Dit is nie die gevolg van innerlike waarde nie, maar dit is die hartslag van die verkondiging van die evangelie, naamlik dat Jesus Christus die sonde weggeneem het. Dat die geloof aan sommige gegee is en dat ander dit nie ontvang nie (DL 1:6) moet nie as 'n aanklag teen God gesien word nie, want geloof vind sy diepste oorsaak in die feit dat God gekies het - já gesê het vir die héle wêreld, want Hy wil dat uiteindelik elke tong sal bely en elke knie sal buig (Rom 14:11), want die JakobEsau voorbeeld dien nie as goddelike onreg nie (Rom 9:14; vgl. Verboom 2005:270). Verkiesing buite Christus om bestaan nie en is nie evangelie nie. Verboom (2005) formuleer dit sterk wanneer hy sê:

Men moet zich nooit los van Christus op het ijs van de verkiezingsleer wagen. Dan is men een waaghals en men komt gegarandeert in een wrak terecht. De verkiezing is geen steriele waarheid, maar een levende waarheid in Christus. (bl. 271)

Met verwysing na Efesiërs 1:4-6 word die klem op God geplaas wat Christus van ewigheid af as fondament van die saligheid gestel het waardeur uitverkorenes deur die Woord en Gees kragdadig tot gemeenskap met Hom getrek word (DL 1:7).

Dit is so dat sommiges verwerp word - nie as 'n ewige goddelike dekreet nie, maar omdat hulle die evangelie verwerp het. God is nie die bewerker van die sonde nie, maar straf die sonde as 'n onberispelike en regverdige regter. Verwerping is dus nie van ewigheid af nie, maar uiteindelik, dit wil sê ná menslike volharding (DL 1:15; vgl. Verboom 2005:221). Verwerping moet nie tot mismoedigheid lei nie, maar tot voortgang om die middels te gebruik, vurig na die tyd van oorvloediger genade te verlang en dit met eerbied en ootmoed af te wag, want Hy het immers beloof om die geknakte riet nie te verbreek en die dowwe lamppit nie te blus nie (Matt 12:20; DL 1:16). Miskien is vermelding van die genadeverbond ' $n$ besondere pastorale vertroosting wat in die Leerreëls opgeneem is (DL 1:17).

Uitverkiesing is die fontein van alle saligheid waaruit geloof, heiligheid en alle saligmakende gawes, ook die ewige lewe vloei (DL 1:9). Uitverkiesing is nie sonder en buite Christus om nie, want sy keuse vir die kruis beteken 'n keuse vir armes, blindes, dowes, en dies meer - 'n keuse vir sondaars. Die kritieke vraag ter beantwoording is of van harte geglo word dat sondes om Christus wil vergewe is? (Joh 8:11; Ef 2:4-5). Wat anders as die sonde kan skeiding maak tussen God en die mens? Die bybelse verlossingsleer is Christosentries en nie dualisties, dit wil sê naas of buite Christus om nie.

Daar is nie ' $n$ is-gelyk-aan-teken tussen om nie die evangelie te hoor, en om nie uitverkore te wees nie. Nie verkore wees nie, is nie ' $n$ verklaring van ongeloof nie, maar is veel meer die gevolg van ongeloof. 'Het geloof rekent niet, maar verwondert zich. In die verwondering liggen zowel de grens als de reikwijdte van ons denken over verkiezing' (Verboom 2005:277). Dit is handig om die DL te lees met die HK in gedagte, wat ook na die sonde en ellende van die mens vra en om van daaruit tóg te hoor dat die sondaar wedergebore word (DL 3/4:12-13; vgl. Van Wyk 2015:10). Dit is onbegryplik, maar 'n gerusstelling om deur die genade van God van harte te glo. Geloof in Christus kom daarop neer dat gelowiges ín Christus 'n nuwe mens word. Ons is, enersyds, vleeslik onder die sonde verkoop, maar tog tegelyk van die doodsbestaan, as gevolg van die sonde, deur Jesus Christus ons Here verlos (Rom 7:14, 25). God verlos van die heerskappy en slawerny van die sonde, maar daarmee word gelowiges nie sondeloos nie. Daarom die voortdurende bede om nie in die versoeking gelei te word nie.

Die mening van Verboom (2005) oor Dordt is van betekenis:

Ik heb het goud van Dordt gevonden. Als een schat in aardse vaten. Het goud van Gods verkiezende liefde, van zijn genade in Christus, van zijn trouw tot het einde. Hij is mijn God en Vader door Jezus Christus. Zijn Geest is mijn Leidsman. (bl. 284)

Die saak van Dordt is onverdiende genade en kan net tersyde gestel word indien genade nie meer bepalend is om die evangelie te verstaan nie. Genade dui nie op 'n groter verdienstelikheid van die een teenoor die ander nie, want indien voorkeur van watter aard ook al ter sprake kom, het genade verval. 'Die uitverkiesing waarvan die Woord getuig is op geen wyse bedoel om mense uit die koninkryk van God uit te sluit nie, maar om almal uit te nooi om die genade in Christus te ontvang. Daarom mag niemand glo dat hy of sy verwerp is nie, en moet elkeen tot die geloof kom dat ons salig is in Christus' (Van Zyl 2004:129).

Dordt: inklusief of eksklusief? Die vraag word vanuit die lig van God se Woord gestel en kan nie anders as Christologies en inklusivisties beantwoord word nie. Daarin setel die troos en bruikbaarheid van die Leerreëls as belydenis wat gelowiges nie met kommer laat oor die vraag of uitverkiesing 
effektief is al dan nie. 'n Interpretasie wat probeer stel dat sommige mense uitverkies is en ander nie, selfs voor die skepping, laat nie reg aan die Leerreëls geskied nie, maar wat meer is, ook nie aan die Skrif nie. Die Gereformeerde tradisie, insluitende die Dordtse Leerreëls, handhaaf 'n konsekwente asimmetrie tussen uitverkiesing en verwerping (Van Zyl 2004:135; vgl. Van Itterzon 1975:142). In die woord genade beluister die Christelike kerk die sedelike inhoud van God se vrymagtige verkiesing (Noordmans 1979:130; vgl. Van Wyk 2015:9).

Uitverkiesing is evangelie. Dit klink ook mee in die Dordtse Leerreëls en dit is nie verbasend dat die Leerreëls steeds deel van die formuliere van eenheid uitmaak nie. Dordt is inklusief, wie homself daarbuite bevind, moet met homself te rade gaan.

\section{Erkenning \\ Mededingende belange}

Die outeur verklaar dat hy geen finansiële of persoonlike verbintenis het met enige party wat hom nadelig of voordelig kon beïnvloed het in die skryf van hierdie artikel nie.

\section{Literatuurverwysings}

Bakhuizen van den Brink, J.N., 1976, De Nederlandse belijdenisgeschriften, Ton Bolland, Amsterdam.

Barth, K., 1958, Kirchliche Dogmatik, 2/1, Evangelischer Verlag, Zollikon.

Calvyn, J., 1986, Institusie van die Christelike godsdiens, deel 2, CJBF, Potchefstroom.

Den Boer, W., 2011, 'Defense or deviation? A re-examination of Arminius's motives to deviate from the "mainstream" Reformed Theology', in A. Goudriaan \& F. Liebur (eds.), Revisiting the Synod of Dordt (1618-1619), pp. 23-48, Brill, Leiden.

Denzinger, H., 2012, Enchiridion symbolorum definitionem et declarationum de rebus fidei et morum / Compendium of creeds, definitions, and declarations on matters of faith and morals, Ignatius, San Francisco, CA.

Donner, J.H. \& Hoorn, S.A., s.a., Acta of handelingen der Nationale Synode, Den Hertog's, Utrecht.

Doornbos, K., 1967, De synode van Dordrecht 1618/19 getoetst aan het recht der kerk, Buiten \& Schipperheijn, Amsterdam.

Goudriaan, A. \& Lieburg, F., 2011, 'Introcuction', in A. Goudriaan \& F. Lieburg (eds.), Revisiting the Synod of Dordt (1618-1619), pp. 9-14, Brill, Leiden.

Graafland, C., 1987a, 'Gereformeerde Scholastiek', Theologia Reformata 30/1, 4-25.
Graafland, C., 1987b, Van Calvijn tot Barth: Oorsprong en ontwikkeling van de leer der verkiezing in het Gereformeerd Protestantisme, Boekencentrum, 's-Gravenhage.

Hoeksema, H.C.,1980, The voice of our fathers, Reformed Free Publishing Association, Grand Rapids, MI.

Kaajan, H., 1914, De pro-acta der Dordtse Synode in 1618, De Vries, Rotterdam.

Krop, H.A., 2011, 'Philosophy and the Synod of Dordt: Aristotelianism, Humanism, and the case against Arminianism', in A. Goudriaan \& F. Lieburg (eds.), Revisiting the Synod of Dordt (1618-1619), pp. 49-80, Brill, Leiden.

Kuyper, H.H., 1899, De post-acta of nahandelingen van de Nationale Synode van Dordrecht in 1618 en 1619 gehouden, Höveker \& Wormser, Amsterdam.

Nederduitsch Hervormde Kerk van Afrika (NHKA), 2016a, Agenda van die een en sewentigste Algemene Kerkvergadering, Argief van die Nederduitsch Hervormde Kerk, Pretoria.

Nederduitsch Hervormde Kerk van Afrika (NHKA), 2016b, Notule van die een en sewentigste Algemene Kerkvergadering, Argief van die Nederduitsch Hervormde Kerk, Pretoria.

NHKA, kyk Nederduitsch Hervormde Kerk van Afrika.

Noordmans, O., 1979, Predestinasie, in Verzamelde werken, deel 2, Kok, Kampen.

Pont, A.D., 1994, Algemene Kerkgeskiedenis: 'n Inleiding tot die Nederlandse Kerkgeskiedenis: Van die beginjare tot 1795, HTS Supplementum 6, Pretoria.

Selderhuis, H.J. (red.), 2006, Handboek Nederlandse Kerkgeschiedenis, Kok, Kampen.

Sinnema, D., 2011a, 'The drafting of the Canons of Dordt: A preliminary survey of early drafts and related documents', in A. Goudriaan \& F. Lieburg (eds.), Revisiting the Synod of Dordt (1618-1619), pp. 291-312, Brill, Leiden.

Sinnema, D., 2011b, 'The Canons of Dordt: From judgement on Arminiasm to confessional standard', in A. Goudriaan \& F. Lieburg (eds.), Revisiting the Synod of Dordt (1618-1619), pp. 313-334, Brill, Leiden.

Spaans, J., 2011, 'Imagining the Synod of Dordt and the Arminian Controversy', in A. Goudriaan \& F. Lieburg (eds.), Revisiting the Synod of Dordt (1618-1619), pp. 335-366, Brill, Leiden.

Van Itterzon, G.P., 1975, 'De Canones van Dordrecht, Dogmenhistorisch', Kerk en Theologie 26, 138-152.

Van Itterzon, G.P., 1979, Franciscus Gomarus, Bouma's, Groningen.

Van Niftrik, G.C., 1949, Een beroerder Israels: Enkele hoofdgedachten in de Theologie van Karl Barth, Callenbach, Nijkerk.

Van Ruler, A.A., 1971, 'Ultra-gereformeerd en vrijzinnig', in Theologisch Werk, Deel 3 , pp. 98-163, Callenbach, Nijkerk.

Van 't Spijker, W., 1987a, 'A. Voorgeschiedenis', in W. van 't Spijker, C.C. de Bruin, H. Florijn, A. Moerkerken \& H. Natzijl (eds.), De Synode van Dordrecht in 1618 en 1619, pp. 11-56, Den Hertog, Houten.

Van 't Spijker, W., 1987b, 'C. De synode en de Remonstranten', in W. van 't Spijker, C.C. de Bruin, H. Florijn, A. Moerkerken \& H. Natzijl, (eds.), De Synode van Dordrecht in 1618 en 1619, pp. 95-120, Den Hertog, Houten.

Van 't Spijker, W., 1991, Geest, Woord en Kerk, Kok, Kampen.

Van Wyk, T., 2015, 'Die Dordtse Leerreëls: 'n Grammatika van geloofstaal gebore uit die nasie-staat-ideologie', HTS Teologiese Studies/Theological Studies 71(3), Art. \#3051, 11 pages. https://doi.org/10.4102/hts.v71i3.3051

Van Zyl, M.S., 2004, 'Die Dordtse Leerreëls as belydenis van volkome troos - 'n bydrae tot die hermeneutiek van belydenisskrifte', NGTT 45, 127-136.

Verboom, W., 2005, De belijdenis van een gebroken kerk, Boekencentrum, Zoetermeer. Weber, O., 1962, Grundlagen der Dogmatik, 2. Band, Neukirchener, Moers. 